\title{
上顎癌治療後長期生存者の調査研究
}

\author{
香川医科大学耳鼻咽喉科学教室（主任：酒井俊一教授） \\ 酒 井 俊一・伊東 真 人 \\ 大阪大学医学部耳鼻咽诶科学教室（主任：松永 亨教授) \\ 吉田淳 一・佐々木 良二
}

\section{CLINICAL OBSERVATION OF THE LONG TERM SURVIVORS AFTER TREATMENT FOR THE MAXILLARY MALIGNANCIES}

SHUN-ICHI SAKAI M. D. and MAHITO ITOH, M. D.

\author{
Department of Otorhinolaryngology, Kagawa Medical School, Kagawa \\ JUN-ICHI YOSHIDA M. D. and RYOHJI SASAKI, M. D.
}

Department of Otorhinolaryngology, Osaka University, Medical School, Osaka

Of the 1102 cases of nasal-and paranasal malignancies, life condition of the long term survivors was studied. The total number of patients were 258 , of which 87 cases have been observed for 59 years, 149 for $10-19$ years and 22 for more than 20 years.

The causes of the patients' death which occurred during the observation period were double cancer, apoplexy, decrepitude etc. As the focus of the apoplexy occurred more frequently on the side of maxillary malignancies, it could be related with the late effect of radiation therapy. The case with no symptom or with slight symptom in the performance status amounted to $80 \%$ of the subjects studied (258 cases), however, the percentages relative to the number of all registered cases (1102 cases) were $29.1 \%$ in the group of 5 years observation period, $22.9 \%$ in 10 years group and $3.4 \%$ in more than 20 years group, respectively. The results suggest the severe circumstance of this disease.

The first factor limiting everyday life was the aging of the patients and the second was the radiation cataract. The cataract always occurred on the affected side, and $87.9 \%$ cases lost their sight in 10 years after the treatment. Even on the eye of the healthy side, the intact vision was found only in $65.8 \%$ of 10 years survivors.

These observations showed that our recent therapy in adequate, but gave a warning in the way to select the indication patients for the radiotherapy. It is most important to avoid the overdosis, to decide the appropriate field and protector, and to reduce the radiation dose on the eye of the healthy side.

As far as the total maxillectomy is concerned, further effort must be given for deciding the cutting margin, and for improving the operation method. Cooperation with plastic surgeon is also suggested. After the operation, attention should be paid to practice the mouth opening and to treat 
the middle ear effusion.

Key words : 上顎癌, 遠隔成績, 実態調查, 放射線障害

A90-0523-30399

はじめに

通常覀性腫瘍の遠隔成績は治療開始時点より 5 年後 の生存率をっって論じられる。しかし治療成績が问上 し， 5 年以上の生存者が相当数になれば，その生活実 態についても注目しなければならない。上䪽癌は鼻副 鼻腔に発生した悪性腫湯を意味し，その治潦として放 射線治療，手術療法などが適用されている．したがっ て治寮後長期にわたり, 鼻腔, 口腔, 視器, 聴器, 脳 などに関する後遺症と顔面の変形加らくる美容上の問 題がある。ある程度の障害は救命のために必要悪とさ れ，認容されてはいるが，夷際にいかなる障害を残し ているかについての調查研究は少ない。詳細な実態調 查により, 過去に行われた治療法に対する反省と, 今 後の治療方針に対する指針を与えることができる。

過去 30 年間にわたる自験例のうち, 治療後 5 年以上 生存し得た症例について, 生活害態, 障害程度などを 調查研究したので，その結果を報告する.

\section{方法}

昭和 32 年から昭和 55 年 12 月までに, 大阪大学なら びに大阪回生病院耳鼻咽喉科において著者らが治療に 関わり，鼻副鼻腔悪性腫瘍として登録された新鮮症例 は 1102 例であった.これを昭和 32 年から昭和 40 年ま
でに治療開始した 350 例，昭和 41 年から昭和 50 年ま でに治療開始した 515 例, 昭和 51 年から昭和 55 年ま でに治療開始した 237 例の 3 群に分けた。昭和 60 年 12 月末時点において, それぞれ 20 年以上観察, 10〜19 年観察, ならびに 5 9 年観察された登録症例群とな る.

各群において観察期間の以前に死亡また檤跡不能 となった症例を除外したものが今回の調査対象症例と なった。すなわち外来受診またはアンケート調査によ り追跡し得た症例は, $5 \sim 9$ 年群 87 例, 10〜19 年群 149 例㧍よび 20 年以上群 22 例であった。これら症例の中 にはその観察期間中に死亡または追跡不能となった症 例もあり，その生前 $1-2$ 年における状態をもって調查 結果とした。これら症例数を表 1 に示した。

調查を行った項目は次のようであった。

I . 一般状態 (performance status)

0. 無症状で社会活動ができ，制限を受けることな く, 発症前と同等にふるまえる (以下無症状と略)

1. 軽度の症状があり, 肉体労働は制限を受けるが, 歩行, 軽労㗢や座業はできる. 例えば軽い家事, 事務 など（以下軽度症状と略）

2. 歩行や身の回りの事はできるが，時に少し介助 がいることもある.軽労働はできないが，日中の $50 \%$

表 1 登録症例数と調祖対象症例数

\begin{tabular}{|c|c|c|c|c|}
\hline 観察期間 & 5 - 9 年 & 10－19年 & 20 年以上 & $=+$ \\
\hline 治療症例数 & 昭和 $51 － 55$ 年 & 昭和 $41 － 50$ 年 & 昭和 $32 \sim 41$ 年 & 中斿 \\
\hline 登録症例数 & 237 & 515 & 350 & 1,102 \\
\hline $\begin{array}{l}\text { 観察期間の前に } \\
\text { 死亡または } \\
\text { 追跡不能例数 }\end{array}$ & 150 & 366 & 328 & 844 \\
\hline 調査対象症例数 & 87 & 149 & 22 & 258 \\
\hline $\begin{array}{l}\text { 観察期間中に } \\
\text { 死亡または } \\
\text { 追跡不能例数 }\end{array}$ & 34 & 40 & 3 & 77 \\
\hline 調查時生存例数 & 53 & 109 & 19 & 181 \\
\hline
\end{tabular}


以上は起居している（以下起居可能と略）

3. 身の回りのある程度のことはできるが，しばし ば介助者がいり，日中の $50 \%$ 以上は就休している(以 下半日就床と略)

4. 身の回りのこともできず，常に介助がいり，終 日就床を必要としている（以下終日就床と略）

II. 仕 事

0. 発症前と同じ仕事をしている

1. 発症前と変わらないが, もともと軽作業であっ た. 家事, 隠居などを含を

2. 老路のため仕事を止めた，定年退職のため転職 Lた

3. 病気のため仕事を変えた

III. 患側眼

0 . 視力良好

1. 視力減退, 0.1 以下, 新聞の見出しが読める位

2. 失明, 眼前手動, 明暗判別可能を含む

3. 眼球疼のため眼球摘出

4. 腫瘍治療のため眼窩内容切除術

IV. 健側眼

0. 視力良好

1. 視力減退

2. 失明

3. 発症前加ら失明

V. 開 口
0 . 正常

1. 軽度障宫, 2 横指

2 . 高度障害, $1 \sim 0$ 横指

VI. 唾液分泌

0 . 正常

1. 障害, いつも含嗽

VII. 食事

0 . 正常

1. 障害, 流動食に近い

VIII. 聴 力

0.ほほ正常

1. 障害, 両耳平均聴力レベル $50 \mathrm{~dB}$ 以下

IX. 頭 痛

0 . ない

1.よくある

\section{I 北景因子について \\ 成 績}

観察期間 5 9 年の登録数は 237 例,対象数は 87 例, 観察期間 10〜19 年の登録数は 515 例，対象数は 149 例，観察期間 20 年以上の登録数は 350 例, 対象数は 22 例であった。その各々について年齢別(表 2)，原発部 位別（表 3)，病理組織別（表 4) ならびに進展度別（表 5) の症例数を示した。

年齢別に見た登録例と対象例との差は対象例におい

表 2 年龄別症例数

\begin{tabular}{|c|c|c|c|c|c|c|}
\hline \multirow{2}{*}{ 年観察期間 } & \multicolumn{2}{|c|}{5 - 9 年 } & \multicolumn{2}{|c|}{ 10-19年 } & \multicolumn{2}{|c|}{ 20一以年 } \\
\hline & 登録数 & 対象数 & 登録数 & 对象数 & 登録数 & 対象数 \\
\hline \multirow{2}{*}{-39 歳 } & 33 & 12 & 60 & 23 & 43 & 5 \\
\hline & $13.9 \%$ & $13.8 \%$ & $11.7 \%$ & $15.4 \%$ & $12.3 \%$ & $22.7 \%$ \\
\hline \multirow{2}{*}{$40 \sim 49$ 歳 } & 37 & 18 & 80 & 34 & 81 & 7 \\
\hline & $15.6 \%$ & $20.7 \%$ & $15.5 \%$ & $22.8 \%$ & $23.1 \%$ & $31.8 \%$ \\
\hline \multirow{2}{*}{$50 \sim 59$ 歲 } & 59 & 29 & 181 & 50 & 123 & 6 \\
\hline & $24.9 \%$ & $33.3 \%$ & $35.1 \%$ & $33.6 \%$ & $35.1 \%$ & $27.3 \%$ \\
\hline \multirow{2}{*}{$60 \sim 69$ 歳 } & 74 & 20 & 136 & 34 & 83 & 4 \\
\hline & $31.2 \%$ & $23.0 \%$ & $26.4 \%$ & $22.8 \%$ & $23.7 \%$ & $18.2 \%$ \\
\hline \multirow{2}{*}{$70 \sim$ 歳 } & 34 & 8 & 58 & 8 & 20 & 0 \\
\hline & $14.3 \%$ & $9.2 \%$ & $11.3 \%$ & $5.4 \%$ & $5.7 \%$ & $0 \%$ \\
\hline 計 & 237 & 87 & 515 & 149 & 350 & 22 \\
\hline 平均年夦 & 56.6 筬 & 54.3 藏 & 56.0 嵗 & 53.0 嘁 & 53.7 筬 & 49.1 嘁 \\
\hline
\end{tabular}


表 3 原発部位別症例数

\begin{tabular}{|c|c|c|c|c|c|c|}
\hline 観察期間 & \multicolumn{2}{|c|}{$5 \sim 9$ 年 } & \multicolumn{2}{|c|}{$10 \sim 19$ 年 } & \multicolumn{2}{|c|}{20 年以上 } \\
\hline 原発部位 & 登録数 & 対象数 & 登録数 & 対象数 & 登録数 & 対象数 \\
\hline 腔 & $\begin{array}{c}20 \\
8.5 \%\end{array}$ & $\begin{array}{c}10 \\
11.5 \%\end{array}$ & $\begin{array}{c}17 \\
3.3 \%\end{array}$ & $\begin{array}{c}8 \\
5.4 \%\end{array}$ & $\begin{array}{c}14 \\
4.0 \%\end{array}$ & $\begin{array}{c}3 \\
13.6 \%\end{array}$ \\
\hline 上 顎 洞 & $\begin{array}{c}197 \\
83.1 \%\end{array}$ & $\begin{array}{c}75 \\
86.2 \%\end{array}$ & $\begin{array}{c}463 \\
89.9 \%\end{array}$ & $\begin{array}{c}131 \\
87.9 \%\end{array}$ & $\begin{array}{c}324 \\
92.6 \%\end{array}$ & $\begin{array}{c}16 \\
72.7 \%\end{array}$ \\
\hline 篲 臂 洞 & $\begin{array}{c}17 \\
7.2 \%\end{array}$ & $\begin{array}{c}2 \\
2.3 \%\end{array}$ & $\begin{array}{c}23 \\
4.5 \%\end{array}$ & $\begin{array}{c}10 \\
6.7 \%\end{array}$ & $\begin{array}{c}9 \\
2.6 \%\end{array}$ & $\begin{array}{c}2 \\
9.1 \%\end{array}$ \\
\hline 前 頭 洞 & 0 & 0 & 6 & 0 & 2 & 0 \\
\hline 蝶形骨洞 & 2 & 0 & 1 & 0 & 1 & 1 \\
\hline 上 顎 部 & 1 & 0 & 5 & 0 & 0 & 0 \\
\hline 計 & 237 & 87 & 515 & 149 & 350 & 22 \\
\hline
\end{tabular}

て多少若年の傾向が見られ，その平均年齢でみると $2 \sim 3$ 歳の差が出ている.また 20 年以上観察例では登 録例において 3 歳程若いことが示され，近年患者層の 高齢化が見られる。

原発部位別に見た登録例と対象例との背景因子に有 意差はなく，いずれも上影洞原発が最多を示す，観察 期間別に見ても同じである.

病理組織別に見た両者の間にも有意差と思われる所 はないが, 傾向として肉腫症例は癌腫症例に比し長期 生存者が少なく，悪性黒色腫症例での対象例は見られ なかった。観察期間別に見ても特別な傾向は見られな (2.

進展度別に見た登録例と対象例との差は，T1から T 3 までは大差なく，T 4 において対象例が減少し，根 治の難しさを示した．また同様にN 1 3 例, M 1 例の 対象例は少なくなっている。そその観察期間別検討では 20 年以上群に括いては T 3 の対象例が少なく, 当時の 治療法の未熟であったことを示した。

II. 調查項目について

各観察期間において調查された一般状態 （performance status）を見ると, 図1のようになり無症状者 は長期観察群の方が多く見られる。しかし無症状者と 軽度症状者との和はいずれの観察期間でも約 $80 \%$ で あり，これは一般状態良好であるため長期生存してい ると理解するべきである。ただ少数とはいえ半日就床， 終日就床など一般状態が悪い者もあり，その大部分は 老齢のためであるが，中には放射線障害によるもの，
術後障害に起因するものもある.

表 6 には観察期間中の死因が示されているが，脳卒 中が多発し，それは必ず患側に起こり，健側の半身不 髄を来している点，放射線障害による脳血管障害と推 察された。

現在の仕事について調查すると図 2 のように過半数 において，発症前と同じ仕事を続け，また発症前から 軽作業であったもの，老齢のため鿵居したものは多い が,病気のため仕事を変えたものは約 $10 \%$ となってい る。

患側眼の障害は図 3 に示されている，筆者らの治療 方針が放射線治療を先行させているため，その大部分 の症例は白内障のため失明している，中には角膜炎加 ら眼球疼を起こし，眼球摘出を要した症例もあった。 特に 20 年以上観察例ではそのような症例が多く,当時 の線源，線量が然らしめたものであろう．少数の視力 良好例は放射線治療を行わなかったか，照射野から外 したものである。

放射線白内障として手術を受けた 28 例の視力を調 查し表 7 に示したが，多少とも網膜変性を合併してい るため，満足な視力を得たものは稀であった。

健側眼の視力は図 4 に示すように, 5 9 年観察では $90 \%$ 良好であったが, 10〜19 年観察で $66 \%, 20$ 年以 上観察で $45 \%$ と隇少し, 視力減退を来すものが增加す る，その多くは放射線白内障であり，放射線治滰時の 散乱線または側方からの照射による被爆が無視できな いことを示した。少数例ながら失明したものもあり， 
表 4 病理組織別症例数

\begin{tabular}{|c|c|c|c|c|c|c|}
\hline \multirow{2}{*}{ 病理組織 } & \multicolumn{2}{|c|}{$5 \sim 9$ 年 } & \multicolumn{2}{|c|}{ 年 $10 \sim 19$ 年 } & \multicolumn{2}{|c|}{ 20年以年 } \\
\hline & 登録数 & 対象数 & 登録数 & 対象数 & 登録数 & 対象数 \\
\hline 癌 & $\begin{array}{c}207 \\
87.3 \%\end{array}$ & $\begin{array}{c}81 \\
93.1 \%\end{array}$ & $\begin{array}{c}470 \\
91.3 \%\end{array}$ & $\begin{array}{c}136 \\
91.3 \%\end{array}$ & $\begin{array}{c}334 \\
95.4 \%\end{array}$ & $\begin{array}{c}21 \\
95.5 \%\end{array}$ \\
\hline 扁平上皮癌 & $\begin{array}{c}167 \\
70.5 \%\end{array}$ & $\begin{array}{c}65 \\
74.7 \%\end{array}$ & $\begin{array}{c}367 \\
71.3 \%\end{array}$ & $\begin{array}{c}99 \\
66.4 \%\end{array}$ & $\begin{array}{c}218 \\
62.3 \%\end{array}$ & $\begin{array}{c}14 \\
63.6 \%\end{array}$ \\
\hline 未分化癌 & 9 & 4 & 25 & 7 & 18 & 3 \\
\hline 移行上皮癌 & 6 & 3 & 3 & 2 & 7 & 0 \\
\hline 腺＼cjkstart癌 & 8 & 3 & 18 & 10 & 5 & 1 \\
\hline 腺様罣胞癌 & 5 & 2 & 6 & 5 & 2 & 0 \\
\hline カルチノイド & 2 & 0 & 1 & 1 & 0 & 0 \\
\hline 粘表皮癌 & 5 & 2 & 8 & 3 & 2 & 0 \\
\hline 腫 & $\begin{array}{c}20 \\
8.4 \%\end{array}$ & $\begin{array}{c}5 \\
5.7 \%\end{array}$ & $\begin{array}{c}37 \\
7.2 \%\end{array}$ & $\begin{array}{c}13 \\
8.7 \%\end{array}$ & $\begin{array}{c}12 \\
3.4 \%\end{array}$ & $\begin{array}{c}0 \\
0 \%\end{array}$ \\
\hline 線 維 肉 腫 & 1 & 0 & 6 & 2 & 3 & 0 \\
\hline 脂肪肉腫 & 1 & 0 & 3 & 1 & 0 & 0 \\
\hline 横紋筋肉腫 & 2 & 0 & 5 & 3 & 1 & 0 \\
\hline 平滑筋肉腫 & 1 & 0 & 0 & 0 & 0 & 0 \\
\hline $\begin{array}{l}\text { 悪性線維 } \\
\text { 組織球球腫 }\end{array}$ & 2 & 1 & 0 & 0 & 0 & 0 \\
\hline 血管肉腫 & 1 & 1 & 0 & 0 & 0 & 0 \\
\hline 骨 肉 腫 & 3 & 1 & 2 & 1 & 1 & 0 \\
\hline 軟骨肉腫 & 0 & 0 & 1 & 1 & 2 & 0 \\
\hline EWING & 0 & 0 & 1 & 0 & 0 & 0 \\
\hline 悪性リンバ腫 & 9 & 2 & 17 & 5 & 5 & 0 \\
\hline 恶性黒色腫 & 8 & 0 & 7 & 0 & 3 & 0 \\
\hline 嗅神経芽腫 & 2 & 1 & 1 & 0 & 1 & 1 \\
\hline 計 & 237 & 87 & 515 & 149 & 350 & 22 \\
\hline
\end{tabular}

$5 \sim 9$ 年観察の 2 例と 10〜 19 年観察の 5 例においては 盲となった。また 1 例では発症前から健側眼が失明し ており，患側眼が失明したため盲となった。

過半数に扔いては手術を行わずに長期生存している が，図５に示すように，上顎全摘出術による生存者も 少なくない. 20 年以上観察群では当時の治療方針が手 術優位であったため上頡全摘出術による生存者の割合
が大となっている，上碩全摘出術による顔面変形は避 け難く，また少数ながら眼窩内容切除術を併用したも の，広範上顎全摘出術として顔面皮图を切除したもの など, 顔面変形の強い症例も見られる。

その他の障害の頻度を表 8 に示した。開口障害は上 顓全摘出術の後遺症として現れるが, 術後の開口練習 により 2 横指またはそれ以上に開口可能なものが多 
表 5 進展度別症例数

\begin{tabular}{|c|c|c|c|c|c|c|}
\hline 観察期間 & \multicolumn{2}{|c|}{5 -9 年 } & \multicolumn{2}{|c|}{$10 \sim 19$ 年 } & \multicolumn{2}{|c|}{20 年以年 } \\
\hline 進展度 & 登録数 & 対象数 & 登録数 & 对象数 & 登録数 & 対象数 \\
\hline T 1 & $\begin{array}{c}12 \\
5.1 \%\end{array}$ & $\begin{array}{c}5 \\
5.7 \%\end{array}$ & $\begin{array}{c}16 \\
3.1 \%\end{array}$ & $\begin{array}{c}7 \\
4.7 \%\end{array}$ & $\begin{array}{c}3 \\
0.9 \%\end{array}$ & 0 \\
\hline T 2 & $\begin{array}{c}59 \\
24.9 \%\end{array}$ & $\begin{array}{c}31 \\
35.6 \%\end{array}$ & $\begin{array}{c}138 \\
26.8 \%\end{array}$ & $\begin{array}{c}57 \\
38.3 \%\end{array}$ & $\begin{array}{c}86 \\
24.6 \%\end{array}$ & $\begin{array}{c}13 \\
59.1 \%\end{array}$ \\
\hline T 3 & $\begin{array}{c}101 \\
42.6 \%\end{array}$ & $\begin{array}{c}41 \\
47.1 \%\end{array}$ & $\begin{array}{c}223 \\
43.3 \%\end{array}$ & $\begin{array}{c}70 \\
47.0 \%\end{array}$ & $\begin{array}{c}184 \\
52.6 \%\end{array}$ & $\begin{array}{c}8 \\
36.4 \%\end{array}$ \\
\hline $\mathrm{T} 4$ & $\begin{array}{c}65 \\
27.4 \%\end{array}$ & $\begin{array}{c}10 \\
11.5 \%\end{array}$ & $\begin{array}{c}138 \\
26.8 \%\end{array}$ & $\begin{array}{c}15 \\
10.1 \%\end{array}$ & $\begin{array}{c}77 \\
22.0 \%\end{array}$ & $\begin{array}{c}1 \\
4.5 \%\end{array}$ \\
\hline $\mathrm{N} 1 \sim 3$ & $\begin{array}{c}19 \\
8.1 \%\end{array}$ & $\begin{array}{c}3 \\
3.4 \%\end{array}$ & $\begin{array}{c}67 \\
13.0 \%\end{array}$ & $\begin{array}{c}6 \\
4.1 \%\end{array}$ & $\begin{array}{c}34 \\
9.7 \%\end{array}$ & 0 \\
\hline M1 & 0 & 0 & $\begin{array}{c}1 \\
0.2 \%\end{array}$ & 0 & $\begin{array}{c}2 \\
0.6 \%\end{array}$ & 0 \\
\hline 計 & 237 & 87 & 515 & 149 & 348 & 22 \\
\hline
\end{tabular}

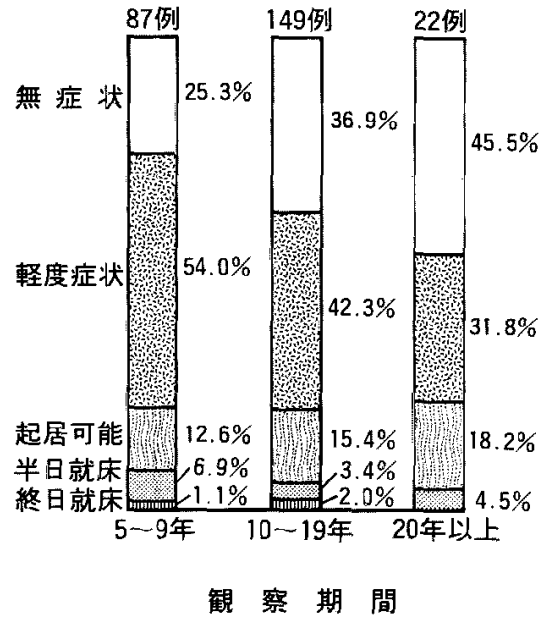

図 1 上顎癌治療後の一般状態(PS)

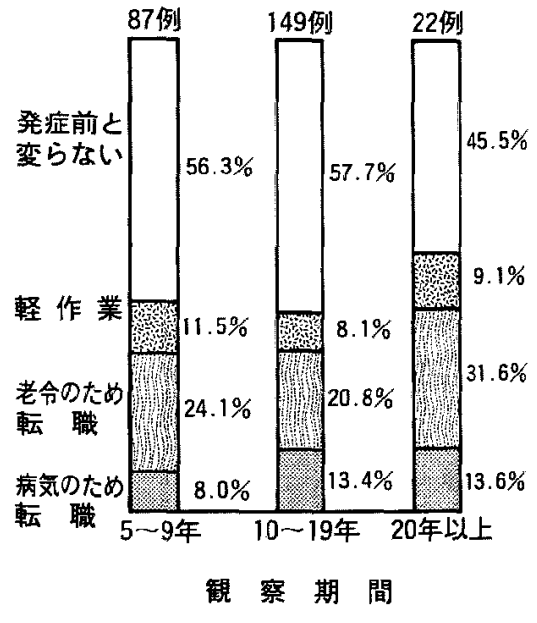

図 2 上顎癌治療後の仕事
い.しかし $10 \%$ 前後の症例では高度の開口障害を訴え ている。また唾液分泌障害, 食事の障害, 聴力障害, 頭痛など高度なものが少数例ながら見られる。

10 年以上生存者において生活を脅加す要因を探る ため, 種々な角度から集計したが，そのうち治療開始 時の年柃, 放射線治療の総線量, 拡大上敛全摘出術に ついて検討した。症例は $10 \sim 19$ 年観察群と 20 年以上 観察群とを加えた 171 例であり，その調查概要は表 9
の通りである。

10 年以上経過した後, 衰弱, 老衰死または脳卒中死 を起こすことに関係があると考えられた 3 群につい て，それらの発来頻度を集計し比較検討した。.まず治 療開始時 60 歳以上の高齢者は 10 年経過すれば 70 歳 以上となり, 20 年経過すれば 80 歳以上となる.したが ってこの上うな高龄者群では衰弱死，脳卒中死の頻度 が高くなることは避けられない。次に照射線量が 7000 
表 6 調查対象例の概要

\begin{tabular}{|c|c|c|c|c|}
\hline \multicolumn{2}{|c|}{ 調查項目 } & $5 \sim 9$ 年 & 10－19年 & 20 年以上 \\
\hline 調 & 健 在 & $\begin{array}{c}50 \\
57.5 \%\end{array}$ & $\begin{array}{c}92 \\
61.7 \%\end{array}$ & $\begin{array}{c}18 \\
81.8 \%\end{array}$ \\
\hline 查 & 担癌 & 0 & $\begin{array}{c}4 \\
2.7 \%\end{array}$ & 0 \\
\hline 生 & 衰 弱 & $\begin{array}{c}3 \\
3.4 \%\end{array}$ & $\begin{array}{c}13 \\
8.7 \%\end{array}$ & $\begin{array}{c}1 \\
4.5 \%\end{array}$ \\
\hline 存 & 小 計 & $\begin{array}{c}53 \\
60.9 \%\end{array}$ & $\begin{array}{c}109 \\
73.2 \%\end{array}$ & $\begin{array}{c}19 \\
86.3 \%\end{array}$ \\
\hline \multirow{3}{*}{$\begin{array}{c}\text { 観 } \\
\text { 筫 } \\
\text { 間 } \\
\text { 中 } \\
\text { R } \\
\text { 死 } \\
\text { 亡 }\end{array}$} & 原 病 死 & $\begin{array}{c}7 \\
8.0 \%\end{array}$ & $\begin{array}{c}2 \\
1.3 \%\end{array}$ & $\begin{array}{c}1 \\
4.5 \%\end{array}$ \\
\hline & 重複癌死 & $\begin{array}{c}4 \\
4.6 \%\end{array}$ & $\begin{array}{c}7 \\
4.7 \%\end{array}$ & 0 \\
\hline & 脳卒中死 & $\begin{array}{c}6 \\
6.9 \%\end{array}$ & $\begin{array}{c}7 \\
4.7 \%\end{array}$ & $\begin{array}{c}1 \\
4.5 \%\end{array}$ \\
\hline \multirow{3}{*}{$\begin{array}{l}\text { ま } \\
\text { た } \\
\text { は } \\
\text { 追 } \\
\text { 跡 } \\
\text { 能 }\end{array}$} & $\begin{array}{c}\text { 老衰死 } \\
\text { など }\end{array}$ & $\begin{array}{c}8 \\
9.2 \%\end{array}$ & $\begin{array}{c}12 \\
8.1 \%\end{array}$ & $\begin{array}{c}1 \\
4.5 \%\end{array}$ \\
\hline & 追跡不能 & $\begin{array}{c}9 \\
10.3 \%\end{array}$ & $\begin{array}{c}12 \\
8.1 \%\end{array}$ & 0 \\
\hline & 小 計 & $\begin{array}{c}34 \\
39.1 \%\end{array}$ & $\begin{array}{c}40 \\
26.8 \%\end{array}$ & $\begin{array}{c}3 \\
13.6 \%\end{array}$ \\
\hline & 計 & 87 & 149 & 22 \\
\hline
\end{tabular}

表 7 白内障摘出者の視力

\begin{tabular}{|c|c|c|c|c|}
\hline $\begin{array}{l}\text { 観察 } \\
\text { 視力 }\end{array}$ & $5-9$ 年 & $10 \sim 19$ 年 & 21 -以上 & 計 \\
\hline 良 好 & 0 & $\begin{array}{c}1 \\
6.3 \%\end{array}$ & 0 & $\begin{array}{c}1 \\
3.6 \%\end{array}$ \\
\hline 減 退 & $\begin{array}{c}7 \\
77.8 \%\end{array}$ & $\begin{array}{c}2 \\
12.5 \%\end{array}$ & $\begin{array}{c}2 \\
66.7 \% \\
\end{array}$ & $\begin{array}{c}11 \\
39.3 \% \\
\end{array}$ \\
\hline 失 明 & $\begin{array}{c}2 \\
22.2 \%\end{array}$ & $\begin{array}{c}13 \\
81.2 \%\end{array}$ & $\begin{array}{c}1 \\
33.3 \%\end{array}$ & $\begin{array}{c}16 \\
57.1 \% \\
\end{array}$ \\
\hline 計 & 9 & 16 & 3 & 28 \\
\hline
\end{tabular}

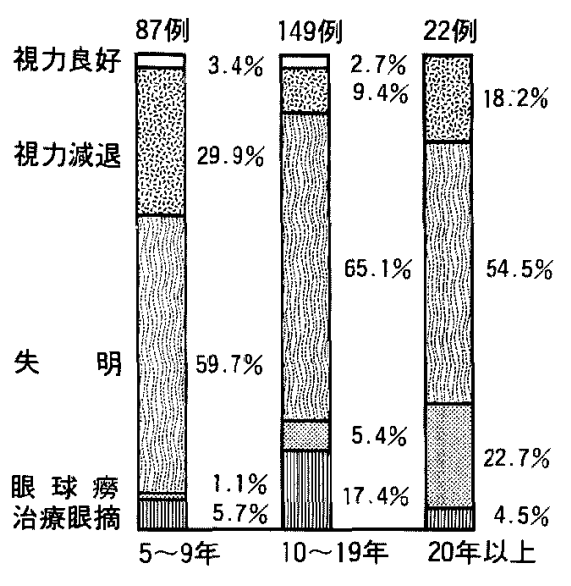

観 察 期 間

図 3 上顎癌治療後の患側眼の状態

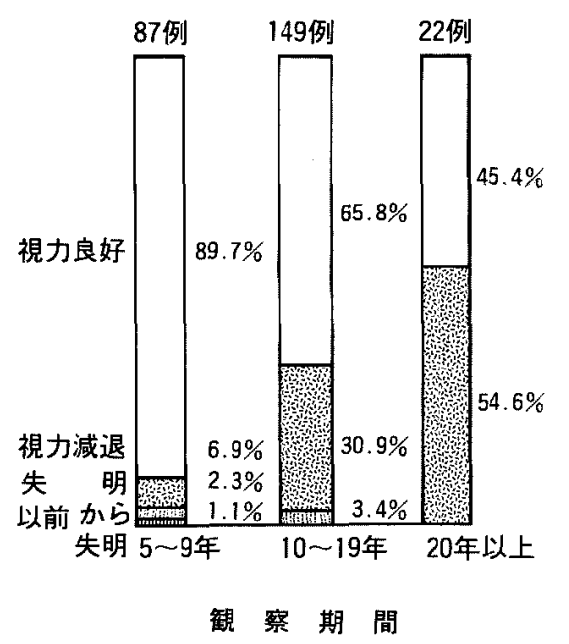

図 4 上㖽癌治療後の健側眼の状热

$\mathrm{rad}$ 以上になると晚発性障害も現れ易く, 衰弱死, 脳 卒中死の頻度が增す。 また应大上顎全摘出術を施行さ れた症例では衰弱を速める傾向が見られる。

10 年以上経過した症例の一般状態を上記と同一の 群についてみると, 表 10 のようになる.10 年以上生存 者の半日就床，終日就床など，制限された生活状態の ものは $3.5 \%$ およ゙゙ $1.8 \%$ に見られるが, 治療開始時 60 歳以上の高齢者, 照射線量が 7,000 rad 以上の者, 拡大上額全摘出術を受けた者では，これら高度制限を 余儀なくされた状態の者の頻度が増し，一般状態を劣 悪にさせる因子であることが明らかである。

10 年以上生存者の中にも 4 例の担癌生存と 3 例の 


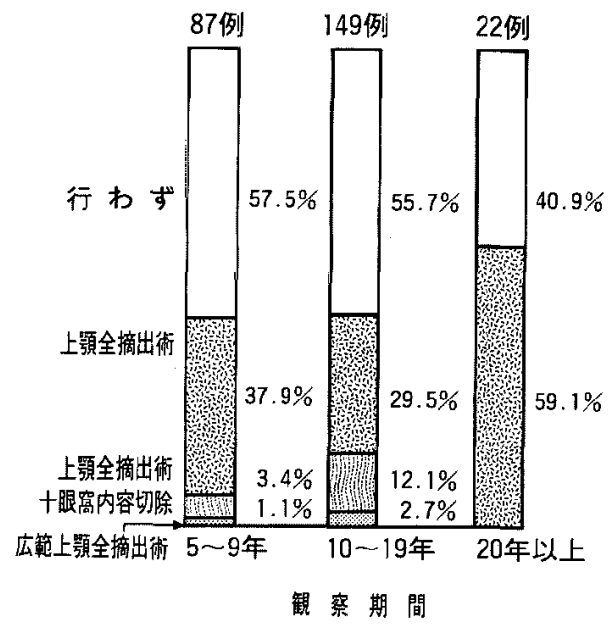

図 5 上顎全摘出術を指標にした形態

\begin{tabular}{l|ccc}
\multicolumn{4}{c}{ 表 $8 \quad$ その他の障害頻度 } \\
\hline
\end{tabular}

表 910 年以上生存者の調査概要

\begin{tabular}{|c|c|c|c|c|c|}
\hline \multicolumn{2}{|c|}{ 調查項目 } & $\begin{array}{l}10 \text { 年以上 } \\
\text { 生存者 }\end{array}$ & $\begin{array}{r}\text { 治療開始時 } \\
60 \text { 歳以上 }\end{array}$ & $\begin{array}{l}\text { 照射線量 } \\
7000 \text { rad以上 }\end{array}$ & $\begin{array}{l}\text { 拡大上顎 } \\
\text { 全摘出絩 }\end{array}$ \\
\hline \multirow{3}{*}{$\begin{array}{l}\text { 調 } \\
\text { 查 } \\
\text { 時 } \\
\text { 生 } \\
\text { 存 }\end{array}$} & 健 在 & $\begin{array}{c}110 \\
64.3 \%\end{array}$ & $\begin{array}{c}25 \\
54.3 \%\end{array}$ & $\begin{array}{c}21 \\
42.9 \%\end{array}$ & $\begin{array}{c}12 \\
54.5 \%\end{array}$ \\
\hline & 担 癌 & $\begin{array}{c}4 \\
2.3 \%\end{array}$ & $\begin{array}{c}1 \\
2.2 \%\end{array}$ & $\begin{array}{c}2 \\
4.1 \%\end{array}$ & 0 \\
\hline & 衰弱 & $\begin{array}{c}14 \\
8.2 \%\end{array}$ & $\begin{array}{c}10 \\
21.7 \%\end{array}$ & $\begin{array}{c}4 \\
8.2 \%\end{array}$ & $\begin{array}{c}3 \\
13.6 \%\end{array}$ \\
\hline \multirow{2}{*}{$\begin{array}{l}\text { 観 } \\
\text { 祭 } \\
\text { 期 } \\
\text { 中 } \\
\text { 中 }\end{array}$} & 原病死 & $\begin{array}{c}3 \\
1.8 \%\end{array}$ & 0 & 0 & $\begin{array}{c}1 \\
4.5 \%\end{array}$ \\
\hline & 重複癌死 & $\begin{array}{c}7 \\
4.1 \%\end{array}$ & $\begin{array}{c}1 \\
2.2 \%\end{array}$ & $\begin{array}{c}3 \\
6.1 \%\end{array}$ & $\begin{array}{c}2 \\
9.1 \%\end{array}$ \\
\hline \multirow{3}{*}{$\begin{array}{l}\text { 死 } \\
亡 \\
\text { 㕛 } \\
\text { は } \\
\text { 追 } \\
\text { 跡 } \\
\text { 甭 }\end{array}$} & 脳卒中死 & $\begin{array}{c}8 \\
4.7 \%\end{array}$ & $\begin{array}{c}4 \\
8.7 \%\end{array}$ & $\begin{array}{c}5 \\
10.2 \%\end{array}$ & $\begin{array}{c}2 \\
9.1 \%\end{array}$ \\
\hline & 老衰死 & $\begin{array}{c}13 \\
7.6 \%\end{array}$ & $\begin{array}{c}2 \\
4.3 \%\end{array}$ & $\begin{array}{c}7 \\
14.3 \%\end{array}$ & $\begin{array}{c}2 \\
9.1 \%\end{array}$ \\
\hline & 追跡不能 & $\begin{array}{c}12 \\
7.0 \%\end{array}$ & $\begin{array}{c}3 \\
6.5 \%\end{array}$ & $\begin{array}{c}7 \\
14.2 \%\end{array}$ & 0 \\
\hline & 計 & 171 & 46 & 49 & 22 \\
\hline
\end{tabular}


表 1010 年以上生存者の一般状態

\begin{tabular}{|c|c|c|c|c|}
\hline 一般状態 群 & $\begin{array}{l}10 \text { 年以上 } \\
\text { 生存者 }\end{array}$ & $\begin{array}{r}\text { 治療開始時 } \\
60 \text { 歳以上 }\end{array}$ & $\begin{array}{c}\text { 照射線量 } \\
7,000 \mathrm{rad} \text { 以上 }\end{array}$ & $\begin{array}{l}\text { 拡大上顎 } \\
\text { 全摘出術 }\end{array}$ \\
\hline 無 症 状 & $\begin{array}{c}65 \\
38.0 \%\end{array}$ & $\begin{array}{c}9 \\
19.6 \%\end{array}$ & $\begin{array}{c}15 \\
30.6 \%\end{array}$ & $\begin{array}{c}8 \\
36.4 \%\end{array}$ \\
\hline 軽度症 状 & $\begin{array}{c}70 \\
40.9 \%\end{array}$ & $\begin{array}{c}22 \\
47.8 \%\end{array}$ & $\begin{array}{c}22 \\
44.9 \%\end{array}$ & $\begin{array}{c}8 \\
36.4 \%\end{array}$ \\
\hline 起 居 可能 & $\begin{array}{c}27 \\
15.8 \%\end{array}$ & $\begin{array}{c}9 \\
19.6 \%\end{array}$ & $\begin{array}{c}8 \\
16.3 \%\end{array}$ & $\begin{array}{c}4 \\
18.2 \%\end{array}$ \\
\hline 半日就床 & $\begin{array}{c}6 \\
3.5 \%\end{array}$ & $\begin{array}{c}3 \\
6.5 \%\end{array}$ & $\begin{array}{c}3 \\
6.1 \%\end{array}$ & $\begin{array}{c}1 \\
4.5 \%\end{array}$ \\
\hline 終日就床 & $\begin{array}{c}3 \\
1.8 \%\end{array}$ & $\begin{array}{c}3 \\
6.5 \%\end{array}$ & $\begin{array}{c}1 \\
2.0 \%\end{array}$ & $\begin{array}{c}1 \\
4.5 \%\end{array}$ \\
\hline 計 & 171 & 46 & 49 & 22 \\
\hline
\end{tabular}

表 11 10年以上生存者のうち担癌生存，原病死症例の一覧

\begin{tabular}{|c|c|c|c|c|c|c|c|c|c|c|c|}
\hline & 年舲 & 性 & 原発部位 & 病理組織 & 進展 度 & 放射楾治療 & 手 & 術 & 再 発 時 & 再発部位 & 生存年数 \\
\hline \multirow{4}{*}{$\begin{array}{l}\text { 癌生存 } \\
\text { 生 }\end{array}$} & 28 & 우 & 上顎 洞 & 腺様露胞癌 & T2N0M0 & $9,000 \mathrm{rad}$ & 全 & 摘 & 8年 & 肺 & 15年 \\
\hline & 37 & 우 & 上顎 洞 & 腺樣戬胞癌 & T2NOM0 & $8,000 \mathrm{rad}$ & 全 & 摘 & 9年 & 肺 & 13年 \\
\hline & 66 & 우 & 上 顎 洞 & 徧平上皮癌 & T3N1M0 & $5,000 \mathrm{rad}$ & \multicolumn{2}{|c|}{ 全摘頸廓 } & 10年 & 局所 & 12年 \\
\hline & 51 & $\hat{\delta}$ & 籂 骨 洞 & 聏平上皮癌 & T2N2M0 & $5,000 \mathrm{rad}$ & \multicolumn{2}{|c|}{ 行わず } & 5年 & 钼 & 10年 \\
\hline 原 & 49 & 우 & 鼻 & 嗅神経芽腫 & T2N0M0 & $5,000 \mathrm{rad}$ & \multicolumn{2}{|c|}{ 行わず } & 7年 & 局 & 20 年 \\
\hline 病 & 58 & 우 & 上顎 洞 & 横紋筋肉腫 & T3N0M0 & 行わず & \multicolumn{2}{|c|}{ 全摘眼摘 } & 7年 & 局 & 11年 \\
\hline 夕 & 55 & 우 & 上顎 洞 & 骨 肉 - 腫 & T3NOMO & $5,000 \mathrm{rad}$ & \multicolumn{2}{|c|}{ 行わず } & 10年 & 局 & 11年 \\
\hline
\end{tabular}

観察期間中病死を認めた。また 7 例の重複癌死も注目 すべきである.それらの症例一覧を表 11 , 表 12 に示し た.

最後に著者の第 1 例として治療され, 29 年後の現在 当健在な症例を報告する。

症例：38 歳男子, 昭和 32 年 1 月初䛦, 4 力月前から 左㐭閉，血性鼻漏を訴え，2力月前から左煩部腫脹， 㴹痛が現れ，左上 6 番を抜歯するも軽快せず，1力月 前加ら硬口蓋の軽度腫脹と頭重を訴える。

現症は左鼻腔側壁の内方偏位，煩部腫脹，硬口蓋腫 脹あり, 硬口蓋加ら試験切除を行い中等度分化扁平上 皮癌と診断された. $\mathrm{X}$ 線像では眼窩底, 洞内壁, 洞下 壁の骨破壊あるも洞後壁と翼状突起健在, 進展度は
T 3 N 0 M 0 と判定された。

治療は $200 \mathrm{KVPX}$ 線の直交 2 門で, 計 $4,000 \mathrm{rad} / 4$ 週を照射， 1 力月後に左上顎全摘出術と左頸部郭清術 を施行,その 2 週後にラジウム管による腔内照射約 3,000 rad を追加した.

その後定期的検查により, 29 年間追跡, 昭和 61 年 1 月現在も健在である. 左白内障のため 3 年後には視力 減退，5年後には明暗のみ判ずる失明となった，右視 力は 0.9 を維持している. 発症前中学校の教員であっ たが, 治療後復職し，60歳の停年まで勤続，その後は 軽作業に従事し, 現在 67 歳である. 顔面変形は図 6 の 程度, 開口障害 2 横指方り, 一度特発性鼻出血のため 入院加療したが，現在ほほ無症状である。 
表12 重複癌症例の一覧

\begin{tabular}{|c|c|c|c|c|c|c|c|c|c|}
\hline & & & 第 & 腫 瘍 & \multicolumn{3}{|c|}{ 第 二 腫 瘍 } & \multirow{2}{*}{ 生存年数 } & \multirow{2}{*}{ 生死 } \\
\hline & 年齢 & 性 & 原発部位 & 病理組織 & 発症時 & 発症部位 & 病理組織 & & \\
\hline \multirow{4}{*}{$\begin{array}{c}5 \\
\text { 吸 } \\
5 \\
9 \\
\text { 年 } \\
\text { 観 } \\
\text { 祭 }\end{array}$} & 43 & $\hat{\delta}$ & 上顎洞 & 扁平上皮癌 & 8年 & 肺 & 癌 & 9年 & 死 \\
\hline & 71 & 우 & 上顎洞 & 扁平上皮癌 & 8年 & 肺 & 未分化癌 & 9年 & 生 \\
\hline & 53 & 우 & 上顎洞 & 扁平上皮癌 & 5 年 & 対側上顎洞 & 扁平上皮癌 & 6年 & 死 \\
\hline & 40 & $\hat{o}$ & 上顎洞 & 扁平上皮癌 & 5 年 & 肺 & 癌 & 5年 & 死 \\
\hline \multirow{7}{*}{ 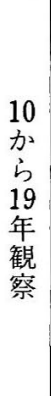 } & 51 & $\hat{0}$ & 上顎洞 & 扁平上皮癌 & 18年 & 対側上顎洞 & 扁平上皮癌 & 20 年 & 死 \\
\hline & 34 & $\hat{o}$ & 上顎洞 & 扁平上皮癌 & 10年 & 鼻 中 隔 & 扁平上皮癌 & 12年 & 死 \\
\hline & 59 & $\hat{\delta}$ & 上顎洞 & 扁平上皮癌 & 7 年 & 食道 & 扁平上皮癌 & 12年 & 死 \\
\hline & 61 & $\hat{0}$ & 上顎洞 & 扁平上皮癌 & 11年 & 肺 & $?$ & 12年 & 死 \\
\hline & 51 & 令 & 上顎洞 & 扁平上皮癌 & 12年 & 丸 & 精上皮腫 & 12年 & 死 \\
\hline & 58 & 우 & 上顎洞 & 扁平上皮癌 & 9年 & 対側上顎洞 & 扁平上皮癌 & 11年 & 死 \\
\hline & 40 & $\hat{o}$ & 上顎洞 & 扁平上皮癌 & 9年 & 左 & 腎 細胞 癌 & 11年 & 生 \\
\hline
\end{tabular}

\section{考察}

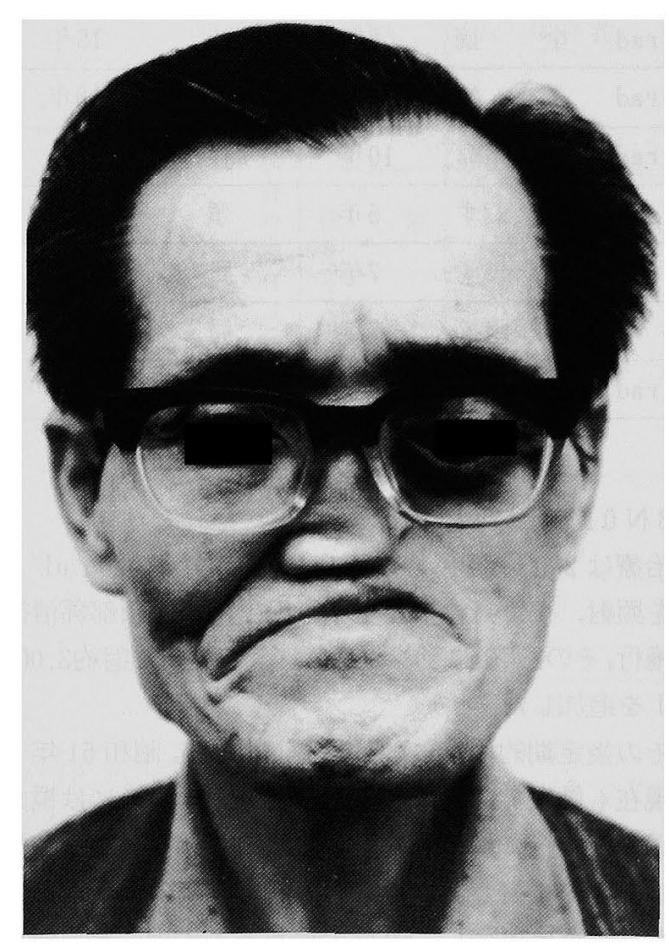

図629年前に治療された患者

本邦における上顎癌に対する治療法の発展は目覚ま

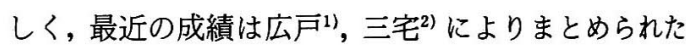
各治療施設からの報告で代表される。また遠隔成績も 生存率のみで論じられるのではなく, 形態と機能を保 存した治療法, 社会復帰が佐藤 ${ }^{3(4)}$ により強調され, 治 療法をめぐる問題点と題して三宅 ${ }^{5)}$ の宿題報告があ る.

しかし症例数が少なく，十分長期に追跡調査するこ との困難さから，10 年を越えた遠隔成續や，生活実態 の報告はなく，それを調查研究する意義は大きいと考 える. 著者ら ${ }^{6) 13)}$ も過去に鼻副鼻腔悪性腫崵の治療成 績を報告し，その一部では長期観察成績に触れたが， なお不十分であった。

今回の調査は著者らが自験した症例で，すでに 5 年 以上の観察期間を経た 1102 例を母数とし, 便宜上 $5 \sim 9$ 年観察群, $10 \sim 19$ 年観察群, 20 年以上観察群の 3 群に分けて，最近の状態を集計した。調査対象症はそ の観察期間前に死亡または追跡不能となった症例を除 き 258 例であった. 5〜9 年観察, 10〜19 年観察, 20 年 以上観察の各群について，登録症例数に対する調查対 象症例数の率を求めると, $87 / 237(36.7 \%), 149 /$ 515 (28.9\%) および $22 / 350(6.3 \%)$ となり，それぞ れ 5 年, 10 年, 20 年時点に扔ける粗生存率を示してい る. 
症例構成は前述のようであるが，そのうち特徴的な 点を挙げると,1) 平均年齢は 50 歳代で, 20 年以上観察 群では少し若年者が多い.2)原発部位は 10 年以上観察 群では, 上領洞が約 $90 \%$ \%てるが, $5 \sim 9$ 年観察群では $80 \%$ 強と少なく, その分, 鼻腔, 管骨洞原発が多くな っている，3)病理組織像は扁平上皮癌が各観察群共約 $70 \%$ \%占め, それに他の癌腫, 肉腫, 悪性黒色腫など が加わる，4)進展度は各観察群の登録数としてほほ均 等でり,対象数は 20 年以上観察群において限局例が 多くなっている。

調查成績のうち,とくに望ましい状態を取りあげて， 全登録症例数に対する割合を算定すると, 表 13 のよう になった。すなわち調查時健在であったものは 5〜9年 観察群, 10 19 年観察群, 20 年以上観察群において $21.1 \%, 17.9 \%$ おるび $5.1 \%$ となっている。また一般 状態が 5 年時点, 10 年時点, 20 年時点において無症状 または軽度症状であったものは $29.1 \% ， 22.9 \%$ およ び $4.9 \%$ \%っった．仕事を変えないまたは軽作業であ るというものは $24.9 \%$ ，19.0\%および $3.4 \%$ あっつ た.

著者らは原則として放射線治療を第一選択とし，現 在ては $5,000 \mathrm{rad} / 5$ 週を標準にしている. 10 年以上前 には 7,000 rad/ 7 週を越す場合もあり, 既報899 のよう
に過線量の障害を警告した. Larson ${ }^{14)}$ は眼症状が手術 法より放射線治療に関連するものが多いことを指摘 し，また Bush ${ }^{15)}$ は放射線障害として視神経障害と骨 壊死の症例を挙げている。，それにしても患側眼の視力 が放射線白内障のため障害されることは現在の治療法 では避け難く，たとえ白内障摘出術を行っても視力回 復は悲観的である．放射線治療を必要以上に行わない こと，照射野やプロテクトを工夫することにより，失 明の時期を遅らせ, 眼球疼などの事態にならないよう にせねばならない。

長期観察を行うと健側眼の障害も無視するわけに行 かず,その視力が良好に保持されているのは 5 年観察, 10 年観察, 20 年観察において，それ杂れ調查対象者の $89.7 \%, 65.8 \%, 45.4 \%$ と次第に少なくなっている. 健側眼にあっては白内障摘出術の成績も良く, 視力回 復を得ているが, 被爆による影響は想像以上のものが ある．側方からの照射野の取り方と照射方向に改良の 余地があるように思える。

上䫈全摘出術は基本的治療法として重要なものであ るが，著者らの治療方針はいわゆる三者併用療法後厳 密な観察を続け, 再発を確認した時点で上顎全摘出術 を施行している．最近の著者の報告では上顎全摘出術 は全症例の $21.6 \%$ に止められ，小野 ${ }^{16)}$ も $19 \%$ と報告

表13望ましい状態の症例数

\begin{tabular}{|c|c|c|c|c|}
\hline \multicolumn{2}{|c|}{ 調査項目 } & $5 \sim 9$ 年 & 10～19年 & 20年以上 \\
\hline \multicolumn{2}{|c|}{ 登録症例数 } & 237 & 515 & 350 \\
\hline \multicolumn{2}{|c|}{ 調查对象症例数と } & 87 & 149 & 22 \\
\hline \multicolumn{2}{|c|}{ 粗生存率 } & $36.7 \%$ & $28.9 \%$ & $6.3 \%$ \\
\hline \multirow{2}{*}{\multicolumn{2}{|c|}{ 調查時健在: }} & 50 & 92 & 18 \\
\hline & & $57.5 \% \quad 21.1 \%$ & $61.7 \% \quad 17.9 \%$ & $81.8 \% \quad 5.1 \%$ \\
\hline \multirow{8}{*}{$\begin{array}{l}\text { 筧 } \\
\text { 祭 } \\
\text { 期 } \\
\text { 間 } \\
\text { 始 } \\
\text { 時 }\end{array}$} & 無症状または & 69 & 118 & 17 \\
\hline & 軽度症状 & $79.3 \% \quad 29.1 \%$ & $79.2 \% \quad 22.9 \%$ & $77.3 \% \quad 4.9 \%$ \\
\hline & 仕事不変 & 59 & 98 & 12 \\
\hline & または軽作業 & $67.8 \% \quad 24.9 \%$ & $65.8 \% \quad 19.0 \%$ & $54.5 \% \quad 3.4 \%$ \\
\hline & 健側眼の & 78 & 98 & 10 \\
\hline & 視力良好 & $89.7 \% \quad 32.9 \%$ & $65.8 \% \quad 19.0 \%$ & $45.5 \%$ \\
\hline & 上顎全摘出術 & 50 & 83 & 9 \\
\hline & を行わず & $57.5 \% \quad 21.1 \%$ & $55.7 \% \quad 16.1 \%$ & $40.9 \%$ \\
\hline
\end{tabular}

注：枠内数字は例数, 左の率は調査刘象症例数を母数とし, 右の率は登録 症例数を母数とした。 
している。もつとも今野17は救命率を上げるためには 根治手術, 再建手術を組み入れた複合療法を主張して おり，著者もスマートに手術された患者は過線量の放 射線治療により救命した患者に比較すると，遙が後 遗症の少ない，快適な日常生活を送ることができると 考える。しかしここでは上顝全摘出術による容貌の変 形を指標として成績を見ると，手術を受けずに救命さ れた患者は各観察期間ごとに調査対象者の $57.5 \%$ ，

$55.7 \%$ おひひ $40.9 \%$ となっている。これは全調查対 象者の $55.0 \%$ になる.この率は十分満足すべき率であ り，これ以上に上げょうとすると，根治率の低下を招 く愚を犯すことになりか朴ない.むしろ必要にして十 分な切除範囲, 術式の改善, 形成外科医との協力体制 などに努力すべきであると考える。

上顎全摘出術にともなって, 開口障害が現れるが, 大部分の症例では, 2 横指の開口が可能であり, 術後 の指導が大切である。

また Myers ${ }^{18)}$ が指摘しているように, 術側の渗出性 中耳炎による難聴は必発と考えられるが，聴力レベル が $50 \mathrm{~dB}$ 上り悪化する症例は少なく, 感音難聴も加齢 のためと見なせる頻度であった.

以上, 治療の主軸となる放射線治療と上枵全摘出術 の影響について述べたが，いわる三者併用療法の 1 つである局所化学療法, あるいは全身的化学療法の長 期障害について明らかなものはなかった。すなおち化 学療法の副作用は短期の障害であると考えられる。

\section{おわりに}

鼻副鼻腔悪性腫痬 1102 例の治療後, 長期に生存し得 た患者の状態について調查することができた，調査対 象数は 258 例であり，その一般状態(PS) が無症状ま たは軽度症状のものは $80 \%$ \%っっだ, 登録症例を母 数にすると，5年観察 $29.1 \%, 10$ 年観察 $22.9 \%, 20$ 年観察 $4.9 \%$ であり，また仕事不変または軽作業のも のは 5 年観察 $24.9 \%, 10$ 年観察 $19.0 \%, 20$ 年観察 3.4 \%となり, 現実の跾しさを示した。

社会復帰を阻む第 1 は老䋛化であり, 第 2 は放射線 白内障である。患側眼の白内障は放射線治療により必 発であり，その 10 年後の失明は調査対象例の $87.2 \%$ に及で, 健側眼に抢いても視力良好なものは $63.2 \%$ に 止まった。

上顎全摘出術は必要に応じて施行し, なるべく保存 的治療の方針をとって来たので, 調查対象例の $55.0 \%$ では形態を保存し得た。
今回の調查結果は最近の治療方針が妥当であること を示したが、なお放射線治療の適応を厳格にし, 過照 射を避け，照射野やプロテクトを工夫して失明の時期 を遅らせ，健側眼への被爆を隇少させるなど，改善の 必要性を示唆し得た。

また上頼全摘出術においては切除範囲, 術式の改善, 形成外科医との協力体制などに努力し, 術後の開口練 習と滲出性中耳炎の処置についても意を注ぐべきであ る.

\section{参考 文 献}

1) 広戸幾一郎他：上顥癌治療の再検討（第 6 回頭頸部 癌愁話会). 耳鼻 $29: 285-345,1983$.

2）三宅浩楖他：上額癌の治療方針. 耳鼻臨床 $78: 683$ $-701,1985$.

3）佐藤靖雄：頭頸部癌の機能外科のありかたについ て. 耳展 $20: 317-359,1977$.

4）佐藤靖雄：放射線科とのチームワークによる頭蹎部 悪性腪痬の治療法について。耳鼻 $19: 259-348$, 1973.

5）三宅浩郷：上額癌の治療をめぐる諸問題, 港北出版, 1984.

6) 酒井俊一他：鼻・副鼻腔悪性腫場 908 例の観察. 耳 鼻 $21: 859-884,1975$.

7) Sakai $\mathrm{S}$ et al : Treatment policy for maxillary sinus carcinoma. Acta Otolaryngol (Stockh) $82: 172-181,1976$.

8）酒井俊一他：上䫑洞癌の治療（トライアルの積み重 ねにもとずく). 耳喉 $50: 500-510 ， 1978$.

9）酒井俊一：上額癌治療の発展. 耳展 $22: 547-553$, 1979.

10）辻本俊弥他：上顎洞を除く鼻副鼻腔癌腫（臨床統計 的観察). 日耳鼻 $86: 149-154,1983$.

11) Sakai $S$ et al: Combined therapy for maxillary sinus carcinoma with special reference to cryosurgery. Rhinology $21: 179-184,1983$.

12) Sakai $S$ et al:Multidisciplinary treatment of maxillary sinus carcinoma. Cancer $52: 1360^{-}$ $136 \overline{4} 1983$.

13）酒井俊一他：頭頸部粘膜に発生した悪性黒色瘇 30 例. 耳鼻臨床 $78: 2799-2812,1985$.

14) Larson DL et al : Preservation of the orbital contents in cancer of the maxillary sinus. Arch Otolayngol $108: 370-372,1982$.

15) Bush SE et al : Carcinoma of the paranasalsinuses. Cancer $50: 154-158,1982$. 
16）小野 勇：上䫟洞がん治療の変遷. 耳鼻 $29: 286-$ 288, 1983.

17) 今野昭義：上顥癌に対する根治手術の適応につい て. 耳鼻臨床 78:687-689，1985.

18) Myers EN et al : Effect of certain head and neck tumors and their management on the ventilatory function of the Eustachian tube. Ann ORL 93 Suppl 114:3-16, 1984.
稿を終わるにのぞみ，協同研究者として御教示と御協力 を頂いた, 大阪大学医学部放射線科真崎規江先生, 大阪大学 雪学部歯科放射線科淵端孟教授, 中村太保先生に深甚の謝 意を表する。な招本研究の一部は昭和 60 年度科学研究課題 60570813 として行った。

(原稿受付 昭和 61.4.14 日)

別刷請求先 テ 761-07 香川県木田郡三木町大字池户 1750

香川医科大学耳鼻咽㬋科学教室 酒井俊一 